\section{LIBERAL ARRANGEMENTS}

IN THE

\section{NEWCASTLE-ON-TYNE INFIRMARY.}

\section{To the Editor of THE LANCET.}

SIR:-On reading your remarks on the pamphlet respecting the Birmingham Infir. mary, I have been a good deal struck by the contrast between the terms of admission at that Institution and at the Infirmary of this place.

Our hospital contains about 160 beds, which are generally fully occupied; but although, occasionally, a few additional beds may be prepared (which the wards will very well permit, as they are never crowded) two patients are never placed in the same bed. The dressing is, generally, altogether performed by the private pupils of the surgeons of the establishment, who are four in number, an equal number of physicians, and a house-surgeon, make up the medical staff.

Pupils are admitted to see the practice, medical and surgical, of the Infirmary, for a fee of five guineas per annum, which is appropriated, not to the benefit of the surgeons, but to the purchase of books for a professional library, to which the pupils have free access, being allowed to take out any books, under certain reasonable regulations. I may add, that during the winter clinical lectures are given by the surgeons in rotation, for the benefit of the pupils, from whom no fee is required for attending them.

The Operating Theatre, where operations are frequent, is open to the pupils, and to all medical practitioners who may feel disposed to witness them.

As regards liberality and facility of access, whether to pupils or other members of the profession, I believe the Infirmary of Newcastle will bear a favourable comparison with any hospital in the kingdom, while to the surgeons of the Institution, no emolument whatever arises from fees of admission. A tolerably successful school of medicine has been established here, for a fer years, which, though not immediately connected with the Infirmary, excites no jealousy amongst its professional officers. Your abedient servant,

T. M. Greenlow.

Newcastle-upon-Tyne, May 23, 1840.

\section{APOTHECARIES' COMPANY, DUBLIN.}

\section{To the Editor of THE LANCET.}

SIR:-In the account of the proceedings of the "British Medical Association," as reported in THE LANCET of last week, there are certain statements made in reference to the "Dublin Company of Apothecaries," which, as Secretary to the Company, I feel myself called upon to contradict.

I therefore request you will allow me, for the present, to disabuse the minds of your readers of any unfavourable impression which these statements may have occasioned, by giving this a place in your next Number; and, in the mean time, $I$ will take care to forward to the "Association" such documentary evidence as will completely demonstrate their incorrectness. I remain, Sir, your obedient servant,

Charles Henry Leet, M.D.

Dublin, Stephen's Green West, June 4, 1840.

\section{NOTE FROM DR. HURST.}

\section{To the Editor of THE LAncet.}

SIR:-There is no established chair of "Medical Jurisprudence" in the Royal Belfast Institution. By the authority of the Joinl Boards of Managers and Visitors $I$ gave a course of lectures (the first ever delivered there) on "Medical Jurisprudence and Police," in the Common Hall of the Belfast Institution, during the last spring, to a class of thirty young gentlemen, which lectures have been officially recognised by the Dublin A pothecaries' Hall, as well as by several other licensing bodies; but whether they shall be repeated or not, will depend entirely on future arrangements.

I have deemed this little piece of information necessary, in reference to a statement regarding me in your last Number, otherwise I would not have intruded myself on your notice at the present time. At a future period I may have something to say anent the present conduct of the Dublin Apothecaries' Company, and their abettors, apologists, and informers. Meanwhile, I remain, your grateful and obedient servant,

London, June 8, 1840.

\title{
PREPARATION OF ACETIC ACID.
}

\section{To the Editor of THE CANCET.}

In the "Remarks on the Pharmacopoeia of the Royal College of Physicians, Edinburgh, 1839, by Mr. Richard Phillips; F.R.S." ("Medical Gazette," No. 33), the following occur on the directions for preparing the acedum aceticum :-

1stly, "I have attempted to follow this process, and if (which I very much doubt) any one else ever did, he must, I think, have found that it is much more easy to fail than to succeed in it."

2ndly, "I have not been able to find this word (accrete) in any dictionary which $I$ have consulted.". 